\title{
THE DESCRIPTION OF ALLERGIC CONTACT DERMATITIS AT GOTONG ROYONG I PRIMARY CLINIC SURABAYA
}

\author{
Dinar A Purworizky ${ }^{1)}$, Erna Harijati ${ }^{2)}$, Lucia R Kartikawati ${ }^{3)}$
}

\begin{abstract}
Introduction : Allergies are one of the immune reaction caused by a substance called an allergen. One way an allergen may affect allergy sufferers is by direct contact. If after contact with an allergen sufferers experience changes in the skin, then those change is called allergic contact dermatitis.

Aim: To describe the allergic contact dermatitis at Gotong Royong I Primary Clinic Surabaya.

Methods : This study is a descriptive study. Data collected by recording the variables such as age, gender, source of allergens, pattern morphology, and the predilection area on data collector sheet based on the results of an examination by a doctor to patients with allergic contact dermatitis at Gotong Royong I Primary Clinic Surabaya in the period from June 13, 2016 until August 31, 2016. The sampling method is using total sampling technique.

Result : This study showed on 53 patients. The highest age group was on a Toddlers group (0-5 years old) with 29 patients $(54.7 \%)$. Women suffered allergic contact dermatitis more than men, as many as 30 patients $(56.6 \%)$. Source of allergens mostly caused by cosmetics, as many as 15 patients $(28.3 \%)$. Morphological pattern was mostly acute pattern, as many as 33 patients $(62.3 \%)$. Predilection areas were located mainly in the area of the upper extremities, as many as 15 patients $(28.3 \%)$.

Conclusion : This study shows that more female subjects were diagnosed with allergic contact dermatitis by doctors. Allergic contact dermatitis in the subjects of the study was mostly caused by cosmetics
\end{abstract}

Keywords : Description, Allergic Contact Dermatitis, age, gender, source of allergen, morphological pattern, predilection area

\footnotetext{
1) Student of Faculty of Medicine, Widya Mandala Catholic University Surabaya, Kalisari Selatan 1 Surabaya Email : itsmednr@gmail.com

2) Dermatology and Venereology Department, Faculty of Medicine, Widya Mandala Catholic University Surabaya, Kalisari Selatan 1 Surabaya

3) Public Health Department, Faculty of Medicine, Widya Mandala Catholic University Surabaya, Kalisari Selatan 1 Surabaya
} 


\section{INTRODUCTION}

Allergy is a kind of many immune reactions found in the community. Data from the Center for Disease Control and Prevention (CDC) notes that the incidence of allergies has tripled from 1993 to 2006. (1) Allergens hit the patients by direct contact and changes in the skin ${ }^{(2)}$ Contact dermatitis allergies occur after previously sensitized skin has contact with allergens by a slow type reaction hypersensitivity. $(3,4)$

A Dutch study found that the prevalence of allergic contact derrmatitis was 12 cases per 1000 population. (5) According to Fitzpatrick, among all cases of contact dermatitis, irritant contact dermatitis become the most cases with $80 \%$, while allergic contact dermatitis was the second with $14 \%-20 \%$. ${ }^{(6)}$

The causes of allergic contact dermatitis are related to ingredients that can trigger allergic reactions in certain individuals such as cosmetics, nickel, perfume, and jewelry, Symptoms and complaints experienced by sufferers also vary. A common symptom is skin that feels dry and itchy, with a rash can occur or worse allergic reaction that is more severe in the affected area. The location of the skin reaction can also vary depending on the source of the allergen.

\section{METHODS}

This research uses descriptive research design. Data retrieval was done once, no intervention was carried out on the population. The study was conducted from June 13 to 31August, 2016 at the Children's and General clinic at Gotong Royong I Primary Clinic Surabaya. The number of research subjects in this study were 53.

Patients of all ages, male or female sex, with symptoms of allergic contact dermatitis, diagnosed with allergic contact dermatitis by doctors, not having other comorbidities, and willing to take part in the study including inclusion criteria. All who did not meet the inclusion criteria were excluded from this study.

The data analysis in this study was descriptive analysis and processed by IBM SPSS Statistics version 22.0 for Windows.

\section{RESULT}

The results showed proportion of subjects: male $43.4 \%$ and women (56.6\%) Table 1 Distribution of Research Subjects by Gender of Allergic Contact Dermatitis Patients at the 2016 Gotong Royong I Primary Clinic Surabaya

\begin{tabular}{cccc}
\hline No. & Gender & Frequency (n) & $\begin{array}{c}\text { Percentage } \\
\mathbf{( \% )}\end{array}$ \\
\hline 1. & Man & 23 & 43,4 \\
2. & Woman & 30 & 56,6 \\
\hline \multicolumn{2}{r}{ Total } & 53 & 100 \\
\hline
\end{tabular}


Age categories according to the Indonesian health department, in the recent study patients in the toddler age group (0-5 years) 29 patients, children (6-11 years) 8 patients, early teen (12-16 years) 2 patients, late adolescent (17-25 years) 2 patients, early adult (26-35) 2 patients, late adult (36 45 years) 4 patients, the early elderly (46-55 years ) were 3 patients, the late elderly (56-65 years) 2 patients, the elderly ( $>65$ years) 1 patient.

Table 2 Distribution of Research Subjects by Age in June to August 2016 at the Gotong Royong I Primary Clinic Surabaya.

\begin{tabular}{clcc}
\hline No. & \multicolumn{1}{c}{ Age } & $\begin{array}{c}\text { Frequency } \\
\text { (n) }\end{array}$ & $\begin{array}{c}\text { Percentage } \\
\text { (\%) }\end{array}$ \\
\hline 1. & $\begin{array}{l}\text { 0-5 years old } \\
\text { (Toddler) }\end{array}$ & 29 & 54.7 \\
2. & $\begin{array}{l}\text { 6-11 years old } \\
\text { (children) }\end{array}$ & 8 & 15.1 \\
3. & $\begin{array}{l}\text { 12-16 years } \\
\text { (Early Youth) }\end{array}$ & 2 & 3.8 \\
4. & $\begin{array}{l}\text { 17-25 years } \\
\text { (Late Youth) }\end{array}$ & 2 & 3.8 \\
5. & $\begin{array}{l}\text { 26-35 years old } \\
\text { (Early Adult) }\end{array}$ & 2 & 3.8 \\
6. & $\begin{array}{l}\text { 36-45 years } \\
\text { (Late Adult) }\end{array}$ & 4 & 7.5 \\
7. & $\begin{array}{l}\text { 46-55 years old } \\
\text { (Early elderly) }\end{array}$ & 3 & 5.7 \\
8. & $\begin{array}{l}\text { 56-65 years } \\
\text { (Late Elderly) }\end{array}$ & 2 & 3.8 \\
9. & > 65 years old & 1 & 1.9 \\
\hline & Total & 53 & 100 \\
\hline
\end{tabular}

Based on the type of allergen source, caused by metals $18.9 \%$, perfume $9.4 \%$, cosmetics $28.3 \%$, topical drugs 9.4\%, antiseptics $7.5 \%$ ) footwear $9.4 \%$, and other causes as much as $17 \%$.
Table 3 Distribution of Research Subjects Based on Allergen Sources in the Gotong Royong I Primary Clinic Surabaya 2016

\begin{tabular}{|c|l|c|c|}
\hline No. & $\begin{array}{l}\text { Source of } \\
\text { Allergens }\end{array}$ & Frequency(n) & $\begin{array}{c}\text { Percentage } \\
(\%)\end{array}$ \\
\hline 1. & Metal & 10 & 18.9 \\
\hline 2. & Perfume & 5 & 9.4 \\
\hline 3. & Cosmetics & 15 & 28.3 \\
\hline 4. & $\begin{array}{l}\text { Topical } \\
\text { medicine }\end{array}$ & 5 & 9.4 \\
\hline 5. & Antiseptic & 4 & 7.5 \\
\hline 6. & Footwear & 5 & 9.4 \\
\hline 7. & $\begin{array}{l}\text { And } \\
\text { others }\end{array}$ & 9 & 17.0 \\
\hline \multicolumn{2}{|r|}{ Total } & 53 & 100 \\
\hline
\end{tabular}

The results for characteristics of the morphological patterns in the study subjects were $62.3 \%$ experiencing acute lesions, $30.2 \%$ had subacute lesions, and $7.5 \%$ experienced chronic lesions.

Table 4 Distribution of Research Subjects Based on Morphological Patterns of Allergic Dermatitis Patients at the Gotong Royong Primary Clinic Surabaya 2016

\begin{tabular}{|c|c|c|c|}
\hline No. & $\begin{array}{c}\text { Morphological } \\
\text { Pattern }\end{array}$ & $\begin{array}{c}\text { Frequency } \\
\text { (n) }\end{array}$ & $\begin{array}{c}\text { Percentage } \\
(\%)\end{array}$ \\
\hline 1. & Acute & 33 & 62.3 \\
\hline 2. & Subacute & 16 & 30.2 \\
\hline 3. & Chronic & 4 & 7.5 \\
\hline & Total & 53 & 100 \\
\hline
\end{tabular}

For the characteristics of the predilection area in the study subjects, $20.8 \%$ were located in the head and neck area, $28.3 \%$ upper extremities, $7.5 \%$ were located in the thoracic and abdominal regions, $20.8 \%$ were located in the genital area, and $22.6 \%$ in the lower limb area. 
Table 5 Distribution of Research Subjects by Predilected Region Allergic Contact Dermatitis Patients in Gotong Royong I Primary Clinic Surabaya 2016

\begin{tabular}{clcc}
\hline No. & $\begin{array}{c}\text { Daerah } \\
\text { Predileksi }\end{array}$ & $\begin{array}{c}\text { Frequency } \\
(\mathbf{n})\end{array}$ & $\begin{array}{c}\text { Percentage } \\
(\mathbf{\%})\end{array}$ \\
\hline 1. & Head and Neck & 11 & 20.8 \\
2. & Upper limb & 15 & 28.3 \\
3. & Thorax and & 4 & 7.5 \\
4. Adomen & Genitalia & 11 & 20.8 \\
5. & Lower limb & 12 & 22.6 \\
\hline & Total & 53 & 100 \\
\hline
\end{tabular}

\section{DISCUSSION}

The results of the study with the highest number in the age group under five are parallel with the theory revealed by Hurwitz which revealed that the skin in toddlers is thinner and produces much less sebaceous gland secretion and sweat which makes it less protective and easily irritated and allergic. ${ }^{(7)}$ According to researchers, these results can be caused by the skin layer and immune system in infants that are still not perfect, making them more susceptible to allergens.

The lowest precentage was in the elderly are parallel with the theory of immunosenescence, which is a decrease in immune function dysregulation related to age, making it more difficult to be sensitized. ${ }^{(15)}$ In addition, the ability to cause an immune response to specific antigens also decreases. ${ }^{(19)}$ Another study also showed that there was a decrease in uptake of antigen and the ability of phagocytosis in elderly so that the immune system was impaired. ${ }^{(20)}$

Allergic contact dermatitis patients are more likely to be female than male. Aesthetic Surgery Journal conclude that there are differences between male and female skin because women produce less oil to protect and maintain skin moisture than men and have a thinner skin structure so it is at more risk to experience skin diseases. Male skin has androgen hormone which causes the skin to grow more hair and oil that can moisturize the skin. ${ }^{(24)}$

In this study it was found that allergic contact dermatitis patients were mostly caused by cosmetics. This is parallel with the research conducted by NACDG, that allergic contact dermatitis is mostly caused by cosmetics because of the various types of cosmetics used daily. ${ }^{(10)}$

Cosmetics are materials that are applied topically with the aim of improving appearance. The ingredients in cosmetics can not be separated from the side effects that can cause allergic contact dermatitis. In this study the cosmetics which caused most allergic contact dermatitis were powder and lotion type because they contained allergens, such as fragrance, paraben, balsam of peru, phenoxyethanol and propylene glycol. ${ }^{(4,10)}$ 
In addition, the results of this study showed that there were more lesions with acute patterns. Allergic contact dermatitis with a pattern of acute lesions consisting of erythema, papules, vesicles, and severe reactions can arise bullae and crusting in the sufferer because allergens cause rapid onset. Nelson revealed that allergic contact dermatitis is generally an acute reaction and limited only on affected area. Signs and symptoms of the disease can be delayed for 7-14 days after exposure if they have not been sensitized before. On repeated exposure, symptoms begin in only a few hours and are more severe because of rapid onset of lesions. (26) According to Hurwitz, repeated exposure to allergens that the body recognizes can cause an acute reaction in just a matter of hours. ${ }^{(14)}$

Lesions in allergic contact dermatitis patients are mostly in the upper extremity area because they are in contact with jewelry containing nickel, cosmetics in the form of powder and lotions, plasters, topical drugs containing Neomycin sulfate, perfume, and deodorants. The results obtained in this study are in line with the theory by Djuanda, that in upper extremities allergic contact dermatitis often occurs after contact with nickel, deodorants, and cosmetics. ${ }^{(3)}$ In this study the highest incidences were found in the upper extremities. Possibly since the upper limb is the body part that is most often used for daily activities. In addition, in the toddler group, upper extremity areas are also often given cosmetic powder or lotion to keep the skin moist to prevent rash on the toddler's skin from being thin and prone to skin damage.

\section{CONCLUSION}

Based on the results of the research on the Overview of Allergic Contact Dermatitis at the Gotong Royong I Primary Clinic Surabaya for the period of June 13 to August 312016, the following conclusions were obtained:

1. The highest age of research subjects was in Toddler group (0-5 years).

2. More female subjects were diagnosed with allergic contact dermatitis by doctors.

3. Allergic contact dermatitis in the subjects of the study was mostly caused by cosmetics

4. More research subjects come with acute morphological patterns.

5. The predilection area of allergic contact dermatitis in this study was mostly found in the upper extremities.

\section{REFERENCES}

1. Perhimpunan Rumah Sakit Seluruh Indonesia. Setiap Tahun, Penderita Alergi di Indonesia Bertambah 30 
Persen. [Internet]. 2012 Apr [cited 2016 Mei 29]. Diunduh dari:

http://www.pdpersi.co.id/content/news. php? mid $=5 \&$ nid $=707 \&$ catid $=23$

2. Dorland, W. A. Newman. Kamus Kedokteran Dorland. Jakarta: Penerbit Buku Kedokteran EGC; 2012. p. 58

3. Djuanda, Adhi. Ilmu Penyakit Kulit dan Kelamin Edisi Keenam. Jakarta: Fakultas Kedokteran Universitas Indonesia; 2011. p. 133-138

4. William D. James, Timothy G. Berger, Dirk M. Elston. Andrew's Diseases of the Skin Clinical Dermatology 12th Edition. United States of America: Elsevier; 2016. p. 93-108

5. Hogan, Daniel J., Allergic Contact Dermatitis. [Internet]. 2015 Apr [cited 2016 Apr 8]. Diunduh dari:

http://emedicine.medscape.com/article/ 1049216-overview\#a2

6. Taylor S, Sood A. Fitzpatrick's Dermatology in General Medicine 7th edition. New York: Mc Graw Hill Book Inc. 2008; 2:2067-73

7. Hudyono J. Dermatosis Akibat Kerja. Majalah Kedokteran Indonesia. 2002; 49(9):16-23

8. Reza, Anggun. Faktor-Faktor yang Berhubungan dengan Kejadian Dermatitis Kontak Alergi di Puskesmas Tapa Kabupaten Bone Bolango. Gorontalo: Universitas Negeri Gorontalo; 2014.

9. Pierre Saint-Mezard, Aurore Rosieres, Maya Krasteva, Frederic Berard, et al. Allergic Contact Dermatitis. European Journal of Dermatology [Internet]. Sep 2004 [cited 2016 Dec 8]. Diunduh dari: https://www.researchgate.net/publicati on/8354799

10. Klaus Wolff, Richard A. Johnson, Arturo P. Saavedra. Fitzpatrick's Color Atlas and Synopsis of Clinical
Dermatology Seventh Edition. United States of America: Mc Graw-Hill; 2013. p. 24-31

11. J. Bourke, I. Coulson, J. English. Guidelines for the Management of Contact Dermatitis: An Update. United Kingdom: British Association Dermatologists; 2009. p. 947

12. Sulaksmono, M. Keuntungan dan Kerugian Patch Test (uji tempel) Dalam Upaya Menegakan Diagnosis Penyakit Kulit Akibat kerja (Occupational Dermatosis). Surabaya: Bagian Kesehatan dan Keselamatan Kerja Fakultas Kesehatan Masyarakat Universitas Airlangga; 2006. p. 3

13. Sugiyono. Metode Penelitian Kuantitatif, Kualitatif, dan R\&D. Bandung: Alfabeta; 2013. p. 115

14. Amy S. Paller dan Anthony J. Mancini. Hurwitz Clinical Pediatric Dermatology; A Textbook of Skin Disorders of Childhood and Adolescence 5th Edition. United States of America: W. B. Saunders Company; 2016 p. 7

15. Gibbs. In Vitro Irritation Models and Immune Reaction. Skin Pharmacology and Physiology; 2009. p. 103

16. Onder M. dan Oztas M. O. Contact Dermatitis in Elderly. Am J Contact Dermatitis; 2003. p. 230

17. Farage MA, Miller KW, Berardesca E, Maibach HI. Clinical Implication of Skin Aging: Cutaneous Disorders in Elderly. Am J Clin Dermatol. 2009; 10(2): 73-86

18. Ghadially R. Aging and the Epidermal Permeability Barrier Implications for Contact Dermatitis. Am J of Contact Dermatitis. 1998; 9(3): 162-169

19. Goh CL, Ling R. A Retrospective Epidemiology Study of Contact Eczema Among the Elderly. 
Singapore: Dermatology Referral

Centre. 1998; 39(10): 442-446

20. Weiskopf D, Weinberger B, Loebenstein BG. The Aging of the Immune System. J European Society for Organ Transplantation. 2009; 22: 41-50

21. Trihapsoro, Iwan. Dermatitis Kontak Alergik pada Pasien Rawat Jalan di RSUP Haji Adam Malik Medan. Sumatera Utara: Bagian Ilmu Penyakit Kulit dan Kelamin Fakultas Kedokteran Universitas Sumatera Utara; 2003. p. 23-26

22. Robert L. Rietschel dan Joseph F. Fowler. Fisher's Contact Dermatitis 6th Edition. United States: BC Decker Inc; 2008. p. 46

23. Suryani, Febria. Faktor-faktor yang Berhubungan dengan Dermatitis Kontak pada Pekerja bagian Processing dan Filing PT. Cosmar Indonesia Tangerang Selatan. Jakarta: Fakultas Kedokteran dan Ilmu Kesehatan Universitas Islam Negeri Syarif Hidayatullah; 2011.

24. International Journal Of Cosmetic Surgery. Aesthetic Surgery Journal. [Internet]. 2011 July [cited 2016 Oct 10]. Diunduh dari: http://www.surgery.org

25. Putra, B. I. Penyakit Kulit Akibat Kerja Karena Kosmetik. Sumatera Utara: Universitas Sumatera Utara; 2008.

26. Aisyah. Gambaran Penyakit Dermatitis Kontak Berdasarkan Usia, Jenis Kelamin, Gejala Klinik, Serta Predileksi di Rumah Sakit Immanuel Bandung Periode Januari 2011Desember 2011. Bandung: Fakultas Kedokteran Universitas Kristen Maranatha; 2012.
27. Ana Hennino, Marc Vocanson, Cyril Chavagnac, et al. Update on the Pathophysiology with Special Emphasis on CD8 Effector T Cells and CD4 regulatory $\mathrm{T}$ Cells. Rio de Janeiro: Anais Brasileiros de Dermatologia; 2005.

28. Dian Adiani, Aulia. Karakteristik Dermatitis Kontak Alergi di RSUP Dr. Kariadi. Semarang: Fakultas Kedokteran Universitas Diponegoro; 2014. 